\title{
Hell as the Here-and-Now
}

\author{
By Daniel F. Short \\ Spring 2007 Issue of KINEMA

\section{HELL AS THE HERE-AND-NOW: IMAGES OF HUMAN TRAVAIL IN TWELFTH- CENTURY EMAKI AND KUROSAWA'S RAN}

AKIRA KUROSAWA'S last major epic film, Ran (translatable as "chaos"), begins in media res with the moment of precipitous decline of the seventy-year-old Hidetora, a medieval-period daimyo. Hidetora gathers together his three sons and two lesser daimyo, lords Fujimaki and Ayabe, for first a hunt, then to issue an edict: Though he will retain his banner and ceremonial title of Great Lord, his oldest son, Taro, will henceforth act as the clan's leader. Hidetora hopes to spend his remaining years as a doting and beloved father. But, as Hidetora's son Saburo warns, such familial peace and bliss is hardly achievable within a world of warriors and their competing ambitions, a world that Hidetora himself helped to create through his many ruthless acts. This meeting of hunter-warriors is both sequel to the violent episodes in which Hidetora subjugated his foes and the penultimate scene for what follows, a renewed struggle among daimyo for total power. In crafting such a struggle as a screen epic, Kurosawa uses colour, space and point of perspective to offer a mimetic, and grandly stylized, context for the grotesque rupture and rending of the human figure that marks the hideous nature of armed combat. A key visual purpose of the film is to put on display the hellish varieties of violence to which humans subject each other as they vie for control over material resources and the psychological comforts offered by a secure state. Throughout the film's drama, characters refer to the travail produced by brutality and betrayal as a hell in itself, and Kurosawa's visuals of death and dying resonate with depictions of emaki [printed handscrolls, ed. note] of the twelfth and thirteenth centuries that were meant to inspire viewers to turn toward the Amida Buddha for release from future suffering.

Ran's treatment of the continuousness of fracture and dissolution, a seeming contradiction in terms, is reflected in its multiple sources of origin, a set of textual interstices that, through Kurosawa's synthesis, suggests structural cohesion. Noh dramas, Japanese historical narratives, and King Lear include some of the cultural sites that Kurosawa excavated as he drafted his screenplay. ${ }^{(1)}$ Interestingly, and quite appropriate given Ran's themes of rebellion and usurpation, these sources often prompted Kurosawa to choose narrative devices in stark contrast to those included in the sources themselves. For example, critic James Goodman recounts that Kurosawa conceived of his story after wondering what would have occurred if idealized father and respected warrior, Motonari Mori (1497-1571), had failed to inspire loyalty in his three sons. ${ }^{(2)}$ Mori's symbolic gesture of asking each son first to break a single arrow, then attempt to break a bundle of arrows is Hidetora's own strategy for demonstrating to his sons the strength found in unity, only Saburo's reaction of using his knee to break the bundle is of Kurosawa's own devising. ${ }^{(3)}$

Kurosawa turns to Shakespeare's play as a potential guide for writing only after he began a script about a ruler challenged with rebellion by his own sons. While the director incorporates from Lear isolated linguistic and visual metaphors, he chooses once again to radically alter some of the source's key elements. ${ }^{(4)}$ Goodwin states that Kurosawa found "puzzling" the absence of a contextualizing past in Lear and his response is to offer a gradual account of how Hidetora engenders his own hell. ${ }^{(5)}$ Indeed, Kurosawa uses several devices to emphasize that human understanding and agency stand at the root of humanity's suffering. Just one such device involves showing the film's evildoers as plotting their own courses, and fates, through a cold and strategic calculus of self-promotion. Still another is the nearly unbearable remorse, and perhaps regret, Hidetora feels through contemplation of his inhumane deeds.

Arguably, the subject of the film is that of the violence of war and the toll that war takes on people and civilizations, rather than, as in Lear, the tragedy of betrayal between individuals. Goodman, too, notes the dominance of conflict in Kurosawa's epic: While war is a prelude to social order in Lear, the clash of armies simply ushers in more combat in the world of Hidetora and his sons, ${ }^{(6)}$ since Lord Ayabe attacks Jiro after he himself usurps his brother's position as head of the Ichimonji. It is crucial to add that Ran gains its visual 
sweep - that of descent from an oasis of verdant, mountainous hills to the unearthly red terrain of a lifeless dessert - by following the course taken by the daimyo and their armies.

Ran's rendering of some of the many hellish forms of human suffering might easily recall to some viewers both the theme and visual effects of the Gaki zoshi (Scroll of Hungry Ghosts) and the Jigoku zoshi (Scroll of Hells). Both are twelfth century emaki consisting of images and text that are based upon the concerns and tenets of Pure Land Buddhism. ${ }^{(7)}$ Scholars consider them as sections of the Rokudô-e or Paintings of the Six Paths (Tokyo National Museum website) ${ }^{(8)}$, which include "the realms of unenlightened heavenly beings, humans, animals, constantly fighting demons, hungry ghosts, and beings in hell." ${ }^{(9)}$ The subject matter is informed by monk Genshin's description of what awaited those not admitted to Amida's Western Paradise in his Ojo yoshu (Essentials of Rebirth), written during the end of the Heian period. ${ }^{(10)}$ The Scroll of Hells shows the eight sections of hell, any one of which could be one's destination of rebirth, depending on one's behaviour in the earthly present. ${ }^{(11)}$ The Scroll of Hungry Ghosts features ghosts as ghastly beings, damned to experience unceasing "hunger and thirst." ${ }^{(12)}$ Even as they are tormented by birds of prey, they are compelled to eat human faeces and cadavers. ${ }^{(13)}$ Paintings of the Rokudo-e were meant to function as aids in meditation by encouraging those who were repulsed by their realistically rendered content to turn towards the Buddha of the Western Paradise for salvation. ${ }^{(14)}$

Such need for the Amida's intervention arose in the Kamakura transition from the glorious cultural epoch of the Heian to the medieval period of the shogun, during which armies clashed to settle disputes over royal succession, and later, the locus of political power. The disorder was such that salvationist sects such as Pure Land Buddhism arose to address what was widely seen as the ushering in of the Mappo, or age in which the breakdown of society brought Buddhist law to its end. ${ }^{(15)}$ Kurosawa, in fact, references this unique dovetailing of culture's flowering with war's destructive forces: In Ran's third scene, we behold the golden Heian-like splendour of Hidetora's court apartments, but which now belong to Taro. Later, we encounter Hidetora's daughter-in-law, Sue, worshipping the Amida Buddha, having become a dedicated follower of the Amida sect after Hidetora ruthlessly slaughtered her parents and gouged out her younger brother's eye, thereby preventing him from taking revenge as an adult. Yet, when Hidetora seeks refuge from Taro at Jiro's castle, she bestows a forgiving smile upon him, a gesture that produces in Hidetora bafflement and consternation. It is at this point during his decline from power that he begins to recognize the horror of his past deeds. Later, he is brought nearly to madness on realizing that his rejection of Saburo and his counsel has led to the needless destruction of the warriors who depended upon him for their survival. On speaking with Hidetora, Sue implies that he, too, should turn to the Amida Buddha, but, in response, he protests in a tone of moral outrage that the gods have left such an evil world, a seeming paradox, unless we realize that Hidetora ably appreciates the distinction between good and bad, just and unjust acts.

In establishing the stylistic mode peculiar to Ran, Kurosawa places much reliance on framing scenes with severe fixity, which allows him to cultivate a form of visual abstraction typically associated with still photography or painting rather than cinema. In speaking of Rashomon, one Kurosawa critic puts forth typical praise for his use of "architectonic $[\mathrm{s}]$," or rhythm of geometric form, to convey the depth of each character's experience, ${ }^{(16)}$ but says that the formal entities of Ran remain formal entities, never achieving congruence with the characters, ${ }^{(17)}$ all of whom remain rather undeveloped and flat. But Kurosawa's overall purpose dictates such use of character. That Hidetora's sons, Taro, Jiro, and Saburo, mean "first son," "second son," and "third son" respectively ${ }^{(18)}$ and that they and others are distinguishable from one another by dress and the colour of army flags ${ }^{(19)}$ underscores their value as nominal variations of a type, mere stopgaps in an ongoing struggle among individuals en masse for self-preservation.

Both a painterly abstraction and a fixity by which the frame is left to be filled by objects encourage the viewer to compare Ran with emaki. Film, in general, functions as a mechanized scroll for a viewer who remains looking ahead in one direction, and Kurosawa, I believe, invokes such a metaphor through his use of opening credits (a story in itself of the film's creation), which serve visually as calligraphic insignias that lay atop the "surface" of the image. For each of these several distinct views of sentries monitoring the area of assembly for daimyo, the credits are uniquely oriented relative to the frame's composition, which also recalls the varied way writing is applied to the sections of a scroll.

Colour at once can suggest a self-contained density of form and an irregularity of volume and line; in addition, 
through a particular composition, the contrast of colours might convey both the immovability of some forms and a volatile tension between others. For Kurosawa, as for the painters of the Scroll of Hells and the Scroll of Hungry Ghosts, the use of colour is an ideal tool for rendering the mutilation of the human body. Kurosawa cannot arrest such images in the manner of a painting, but he does offer a similarly jarring realism of his subject.

Most of the mutilation scenes in Ran arise during Jiro's assault on his own father's army, which occurs at the castle where the latter achieved his first major conquest as a warrior. Images of bodily dismemberment and faces of mad anguish are interlaced through wider views of the determined trot of soldiers pouring gradually into both the castle yard and the castle itself. What is most striking about Kurosawa's arrowpierced corpses is their manner of formal arrangement within the frame, which attaches to the site of murder a profundity distinctly belonging to ritual. One recalls that the very act of viewing the Rokudo-e was based in the ritual of religious contemplation, and the studied arrangement of form may in some way serve as a prompt or a reminder about the scrolls' function. In one example, two wound-erupted bodies stretch out upon pools of blood that balance the figures along a horizontal axis, and each figure's bent right elbow expresses with dramatic flair a strained and contorted existence. In another example, a detail of a Chinese influenced rendering of hell from the Six Realms of Existence (thirteenth century) shows overlymuscled statue-like demons subjecting humans to processes of torture that seem to be as mechanically and as painfully cumbersome as possible. The background colour is that of sand, which serves to intensify the composition's use of red. Twisting ribbons of crimson surround a demon's belt and other tones of blood red fill in the massings of a second torturer's skin and still another's clothes. Several sequences of battle images from Ran are similarly infused with varieties of red, perhaps a visual marker that indicates the unique or special nature of a site overridden by the dead and dying.

Scenes of human suffering in both emaki and Ran offer viewers a privileged, voyeuristic look at the isolation and loneliness faced by individuals so singled out by the destructive forces of the universe. In an image from the Scroll of Hungry Ghosts, this state of alienation and abandonment seems reflected in the scraggy, withering segments of the ghost's terrain. The landscape has either been left to or taken by the parasitic ghosts, though one person, the next victim of the ghosts' feeding, and perhaps already dead, still lies partly upon a blanket, a pathetic last gesture of resistance against inevitable corporeal vanquishment. In Ran, much of Hidetora's exile is spent wandering within and around the ruins of the fallen "first castle." The flat desert exhibits the harsh, isolating features of a hellish terrain and several characters, including Hidetora himself, are preyed upon there by "demons" that spill over from the central arena of combat.

As in twelfth and thirteenth-century emaki, Ran assembles an idiomatic visual taxonomy of human suffering and death. Where the works most diverge is in their respective philosophical assumptions about the world. The now centuries-old Rokudo-e were to serve as objects of contemplation for individual religious renewal or conversion within the post-Heian era of political chaos, while Kurosawa sets out to provide a modern mass audience with visual metonymies of the earthly suffering caused by violent, and all too human, conflict. Indeed, upon Hidetora's demise, following the betrayal of his sons, one of his attendants blames the gods for ignoring human suffering, but Hidetora's only remaining vassal rebukes him for sacrilege, implying that humans have not yet earned divine consideration. 


\section{Notes}

1. James Goodwin, Akira Kurosawa and Intertextual Cinema (Baltimore: The Johns Hopkins University Press, 1994), 196-216.

2. Ibid, 196-200.

3. Ibid, 196.

4. Ibid, 197-214.

5. Ibid, 197-214.

6. Ibid, 214.

7. Joji Okazaki, Pure Land Buddhist Painting, trans. Elizabeth ten Grotenhuis (New York: Kodansha International Ltd., 1977), 167-79.

8. Tokyo National Museum, The Hell Scroll, http://www.emuseum.jp/cgi/pkihon.cgi?SyoID=1\&ID=w049\&SubID= s000. Accessed 5 November 2005.

9. Penelope Mason, History of Japanese Art (New Jersey: Prentice Hall, 2005), 210-11.

10. Okazaki, 175.

11. Ibid, 177.

12. Ibid, 179 .

13. Hideo Okudaira, Emaki: Japanese Picture Scrolls (Tokyo: Charles E. Tuttle Company, 1962), 176-183.

14. Ibid, 177-79.

15. Paul Varley, Warriors of Japan as Portrayed in the War Tales (Honolulu: University of Hawaii Press, 1994), 82-86.

16. Mitsuhiro Yoshimoto, Kurosawa: Film Studies and Japanese Cinema (Chapel Hill: Duke UP, 2002), $185-86$.

17. Ibid, 358.

18. Goodwin, 198.

19. Ibid, 213.

\section{References}

Goodwin, James. Akira Kurosawa and Intertextual Cinema. Baltimore: The Johns Hopkins University Press, 1994.

Ienaga, Saburo. Painting in the Yamato Style. Trans. John M. Shields. New York: John Weatherhill, Inc., 1973.

Mason, Penelope. History of Japanese Art. $2^{\text {nd }}$ ed. Upper Saddle River New Jersey: Prentice Hall, 2005.

Okazaki, Joji. Pure Land Buddhist Painting. Trans. Elizabeth ten Grotenhuis. New York: Kodansha International, 1977.

Kurosawa, Akira. Ran (DVD). Wellspring, 2003. 160 min.

Tokyo National Museum. The Hell Scroll.

http://www.emuseum.jp/cgi/pkihon.cgi?SyoID=1\&ID=w049\&SubID=s000. Accessed 5 November 2005.

Varley, Paul. Warriors of Japan as Portrayed in the War Tales. Honolulu: University of Hawaii Press, 1994. 
Yoshimoto, Mitsuhiro. Kurosawa: Film Studies and Japanese Cinema. Chapel Hill: Duke UP, 2002.

\section{Author Information}

Daniel F. Short is Assistant Professor of English at Nagoya University of Commerce and Business in Japan. His research focuses on the function of metaphorical structure in film, photography, and semiotics. 